\title{
Notch Signaling in Hair Follicle Development
}

Seunghee Bae ${ }^{1}$, Ki-Heon Lee ${ }^{2}$, In-Ho Lee ${ }^{2}$, Mi Kyung Kim² ${ }^{2}$ Jae Ho Lee ${ }^{3^{*}}$

${ }^{1}$ Research Institute for Molecular-Targeted Drugs, Department of Cosmetics Engineering, Konkuk University, Seoul, Korea

${ }^{2}$ Department of Obstetrics and Gynecology, Cheil General Hospital and Women's Healthcare Center, College of Medicine, Dankook University, Seoul, Korea

${ }^{3}$ Laboratory of Molecular Oncology, Cheil General Hospital, College of Medicine, Dankook University, Seoul, Korea

\author{
*Corresponding authors: Jae Ho Lee, \\ Laboratory of Molecular Oncology, Cheil \\ General Hospital, College of Medicine, \\ Dankook University, 17 Seoae-ro, 1-gil, \\ Jung-gu, Seoul 04619, Korea \\ Tel.: +82 220007667 \\ Fax: +82 220007894 \\ Email: jaeho3909@hanmail.net
}

Received May 23, 2017

Revised May 23, 2017

Accepted May 26, 2017

Published September 30, 2017

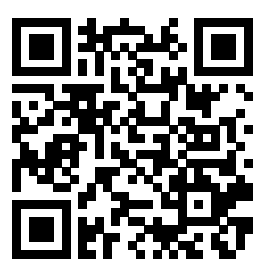

\section{Introduction}

Hair basically serves to protective functions against injury, infection, dehydration, and thermoregulation of skin. Hair shaft is the part of the hair beyond the surface of the skin, and is generated from the hair follicle which is a complex miniorgan of the skin. Hair follicle constitutes the pilosebaceous unit together with its associated structures, including the sebaceous gland, the apocrine gland and the arrector pili muscle (Schlake, 2007; Schneider et al., 2009). Hair follicle is composed of several concentric cylinders of epithelial cells (Powell \& Rogers, 1990). Hair shaft consists of three layers of cells, the medulla, cortex, and hair shaft cuticle cells. Those cells are surrounded by an inner root sheet (IRS) which is composed of cuticle cells, Huxley's and Henley's layers (Schneider et al., 2009). The companion layer is located between the IRS and outer root sheet (ORS) and can separates the IRS from ORS, which is contiguous with the basal layer of the epidermis. They are produced by the mitotic active cells in the matrix of the hair bulb (Blanpain \& Fuchs, 2006; Coulombe et al., 1989). The mitotically active cells called dermal papilla cells in the matrix are in lower region of hair bulb (Blanpain \& Fuchs, 2006). The upper region of hair bulb is called as the precortex where cells differentiate precursors of IRS and hair shaft (Schneider et al., 2009). The precortex region also contains melanocyte to synthesize and transport melanin granules towards the keratinocytes of the forming hair (Limat et al., 1999). In the uppermost part of its permanent portion, the hair follicle is surrounded by the sebaceous gland. The complex of sebaceous glands and hair follicle generates the mature pilosebaceous unit (Paus et al., 1999). Just under the sebaceous gland, the ORS presents known as the bulge where the hair follicle stem cells are presented (Ohyama, 2007). The hair follicle undergoes cycles of growth (anagen), apoptosismediated regression (catagen) and relative quiescence (telogen). In each cycle, a new hair shaft is formed, and the 
old hair is eventually shed, mostly in an actively regulated process termed exogen. Generation of the new hair shaft depends on the activation of hair-specific epithelial stem cells called hair follicle stem cells (Schneider et al., 2009). Although the hair follicle is highly sensitive to growth factors (Booth \& Potten, 2000), cytokines (Danilenko et al., 1996, Hoffmann et al., 1996), neuropeptides (Holub et al., 2012), and hormones (Fischer et al., 2007, van Beek et al., 2008), the intracellular signaling pathways that paly a functional role in hair follicle homeostasis are major interesting field in cellular and molecular biology. There have been many reports about various cellular signaling pathways controlling the hair cycle to maintain hair follicle homeostasis in their microenvironment called niche (Lee \& Tumbar, 2012; Rishikaysh et al., 2014). The key event for hair follicle regeneration is the molecular communication between hair follicle stem cells in their niche and regulation of signaling pathway during hair cycle in hair bulb. Many studies have been established that the temporal differences of signaling pathway in hair follicle development (Lin et al., 2004; Lin et al., 2009; Plikus et al., 2008). Notch signaling pathway is generally accepted to have a key role in cell asymmetric division and fate determination during stem cell development and tissue homeostasis. In this review, we focus on the recent evidences of regulatory activity of Notch signaling on hair follicle differentiation process, which is referred to cell fate decision.

\section{The role of Notch signaling pathway in hair follicle development}

\section{Basic insights of Notch signaling}

Notch signaling is highly conserved through evolution and is crucial for cell death, proliferation, differentiation, and development (Artavanis-Tsakonas et al., 1999; Sato et al., 2012). Notch, a cell-surface receptor, is a family name of transmembrane proteins sharing special structural characteristics including an extracellular domain consisting of multiple epidermal growth factor (EGF)-like repeats, and Notch intracellular domain (NICD) (Rana \& Haltiwanger, 2011). The canonical Notch signaling pathway is depicted in Figure 1. Notch signaling is initiated by interactions between physically neighboring cells through binding of Notch receptors (Notch1-4) to their cognate Notch ligands (Jagged1-2 and

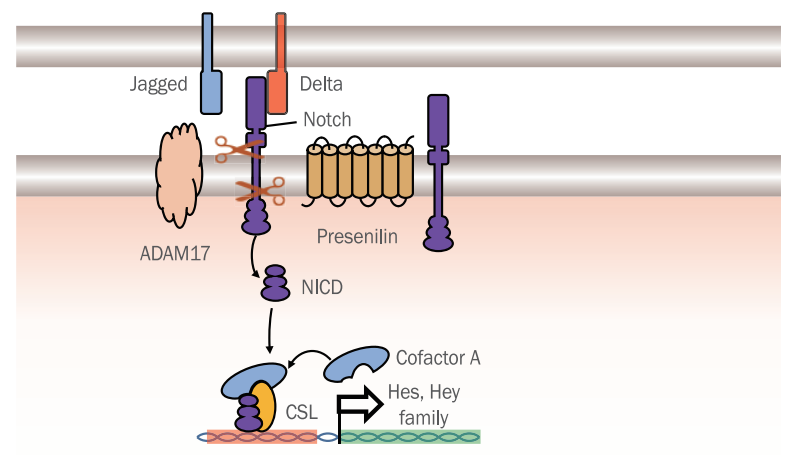

Figure 1. Schematic view of Notch signaling.

Signal transduction from Notch receptor is activated by interaction with its ligands, such as Delta and Jagged. This binding results in a cascade cleavage triggered by the ADAM17 metalloprotease and Presenilin protease. These cleavage reactions result in the release of the NICD. Then, NICD translocates to the nucleus where NICD interacts with transcription factors, CSL and cofactor A. This interaction induces transactivation of downstream target genes including Hes and Hey. ADAM17, ADAM metallopeptidase domain 17; NICD, Notch intracellular domain; CSL, C-promoter binding factor 1 (CBF1), Suppressor of Hairless, Lag1; Hes, Hairy/enhancer of split; Hey, Hairy/enhancer-of-split related with YRPW motif.

Delta1-4) (Chillakuri et al., 2012; Kopan \& Ilagan, 2009). The Notch receptor is translated as a single protein (preNotch). The preproprotein is proteolytically processed in the trans-Golgi network to generate two polypeptide chains that heterodimerize to form the mature cell-surface receptor (Logeat et al., 1998). A Furin-like convertase cleaves preNotch into the extracellular and intracellular domain (S1 cleavage). This results in a heterodimeric receptor with non-covalently associated domains that is transported to the plasma membrane. Notch ligand binding triggers two proteolytic cleavages (S2 and S3). The first, mediated by a disintegrin and metalloproteinase (ADAM) proteinase, occurs in the extracellular domain. $\$ 2$ cleavage sequentially activates the gamma-secretase complex, which is responsible for the second proteolytic cleavage (S3), which located in the transmembrane domain (Brou et al., 2000; Struhl \& Greenwald, 2001). Then, NICD protein is endocytosed and translocated to the nucleus, where it forms a transcriptional complex with the immunoglobulin-like fold, plexins and transcription factors (IPT)-domain-containing C-promoter binding factor 1 (CBF1), Suppressor of Hairless and Lag1 (CSL) (Bray, 2006; Kopan \& Ilagan, 2009). Docking of the ankyrin-repeat domain of Notch to the Rel-homology region 
of the CSL protein generates a composite binding surface for the recruitment of Mastermind-like proteins (Maml). These interactions convert CSL from a transcriptional repressor to an activator by displacing co-repressors (CoR) and histone deacetylases and recruiting histone acetyltransferases. Maml, in turn, recruits additional co-activators (CoA), such as p300. To date, it has been established that combinatorial interactions between Notch transcription complexes and tissue-specific transcription factors enables the diversity of tissue-specific target genes; biological consequences of pathway activation can vary depending on multiple factors, such as cell type-dependent combination of signaling (Sato et al., 2012). Primary Notch target genes include two families of bHLH transcriptional factors Hairy/enhancer of split (Hes) proteins (Hes1 and Hes5) and Hairy/enhancer-of-split related with YRPW motif (Hey) proteins (Hey1 and Hey2) (Grbavec \& Stifani, 1996; Iso et al., 2003). Notch signaling is regulated by other proteins including Numb, Itch, Nrarp, Mint, and Deltex (Krebs et al., 2001; Kuroda et al., 2003; Matsuno et al., 1995; McGill \& McGlade, 2003). Numb and Itch are negative regulators of Notch signaling by preventing nuclear localization and targeting the NICD for degradation through the E3 ligase Itch (McGill \& McGlade, 2003).

\section{Notch signaling pathway in hair follicle development}

Many studies have been carried out on the effects of Notch signaling on stem cell maintenance and cell fate decision in various origins. The effects of Notch signaling in hair follicles has been studied using immunohistochemical analysis and transgenic mouse model carrying either loss or gain of function mutations (Aubin-Houzelstein, 2012; Lee \& Tumbar, 2012; Rishikaysh et al., 2014). Notch is expressed throughout embryogenesis and postnatal period (Favier et al., 2000; Powell et al., 1998). During embryogenesis, Notch1 expressions are detected in the hair placode inner cells and Notch ligand Jagged 1 and 2 expressions are also founded in the same locations as Notch1 transcripts in hair follicles (Favier et al., 2000; Powell et al., 1998). Another Notch ligand, Delta1, is expressed in the dermal papilla and bulb region of embryonic hair follicles during embryogenesis period (Estrach et al., 2008). Vauclair et al. (2005) performed functional comparisons between embryonic and postnatal period. They revealed that inactivation of Notch1 does not perturb the formation and patterning of hair follicle placodes in early embryonic period. However, tissue-specific ablation of Notch1 gene shows a phenotype of hair loss and shortened anagen and premature entry into catagen in late stages of hair follicle development during embryogenesis (Vauclair et al., 2005). These data suggest that Notch1 signaling has a key role in postnatal hair follicle development and homeostasis. Although Notch signaling do not function during hair germ cell induction or cell fate acquisition within the embryonic hair follicle, previous studies reveal that Notch signaling is required to complete terminal differentiation in IRS cells (Cai et al., 2009; Pan et al., 2004). Notch1 is mainly expressed and activated in mitotically active IRS and cortex precursors. In the absence of Notch signaling, a hair shaft still forms and contains properly positioned cells expressing markers for each fate (Pan et al., 2004). This follicular architecture by unstable adherent to each other lead to the transformation of aberrant hair follicles into epidermal cysts during the first anagen by overproliferating ORS cells (Pan et al., 2004). One noteworthy feature is that Notch signaling has a functional role in differentiation process of various progenitor cells rather than in stem cell maintenance of hair follicle germ cells. In this review, recently studied various factors which modulate the Notch signaling pathway during hair follicle differentiation are focused.

\section{1) Musashi family}

The Musashi (Msi) is highly conserved through evolution and is a family name of RNA-binding proteins (Okano et al., 2002; Okano et al., 2005). Two members of the group, such as Msi1 and Msi2, have been identified to date (Sakakibara et al., 1996; Sakakibara et al., 2001). A revealed function of Msi1 is a translational repression of specifically bound mRNAs by directly binding of 3'-untranslated region of targets mRNA (Horisawa et al., 2009). Several researches have revealed that Msi1 plays pivotal roles in maintaining the stem cell status (stemness) of neural stem/progenitor cells in adults and in the development of central nervous system through translational regulation of its target mRNAs (Horisawa et al., 2010; Okano et al, 2005). Furthermore, Msi1 and 2 were expressed in the epidermis and hair follicles at early developmental stages until adulthood in mice (Sugiyama-Nakagiri et al., 2006). Of note, Msi1 and 2 were both expressed in the bulge region of hair follicle in the transition from telogen to anagen phase. During anagen phase, Msi1 and 2 were also expressed in matrix 
cells. These results suggest Msi-positive cells may represent progenitor cells, or hair follicle stem cells.

Recent reports have been noted about the functional crosstalking mechanism between Msi family and Notch signaling in hair follicles (Imai et al., 2001). Imai and colleagues have reported that Msi protein augments the Notch signal through the translational repression of its target, Numb (Imai et al., 2001). Numb functions as a Notch downstream repressor, thereby contributing to the self-renewal of neural and epithelial stem cells. Therefore, further studies will be of interest to examine whether Msi signaling is able to affect the Notch activity for hair follicle stem cell maintenance. Recently, Ma and colleagues were reported that forced Msi2 expression retards anagen entry and consequently, delay hair growth using transgenic and conditional knockout mouse model (Ma et al., 2017). They also showed that Msi2 maintains quiescent stat of hair follicle stem cells in the process of telogen-toanagen transition (Ma et al., 2017). Although they present the Msi2-Hh signaling pathway using bioinformatics analysis, they may not be able to rule out the possibility of Msi and Notch signaling crosstalk (Ma et al., 2017).

\section{2) Reactive oxygen species}

Mitochondria are essential organelles for aerobic respiration to provide the adenosine triphosphate energy by oxidative phosphorylation. The mitochondrial oxidative phosphorylation plays a role in the cellular redox regulation and reactive oxygen species (ROS) generation (Handy \& Loscalzo, 2012). Evidences suggest that stem cells reside in niches characterized by hypoxia and low ROS, both of which are critical for maintaining the potential for self-renewal and stemness (Eliasson \& Jönsson, 2010; Ezashi et al., 2005; Fehrer et al., 2007; Mohyeldin et al., 2010). In the last decade, several studies have revealed that mitochondrial metabolism is a functional regulator of keratinocyte and hair follicle differentiation (Hamanaka \& Chandel, 2013; Hamanaka et al., 2013; Lemasters et al., 2017; Tang et al., 2016). Hamanaka and his colleagues have reported that mitochondrial ROS promote epidermal differentiation and hair follicle development (Hamanaka et al., 2013). They used Krt14-specific Tfam-deleted conditional knockout mouse (TFAM/KRT14-Cre ${ }^{+}$mouse) which was characterized by impaired mitochondrial functions in epidermis and showed that mice lacking Tfam also exhibited the transcriptional suppression of Notch downstream signaling. Although they did not provide a defined mechanism for the activation route of Notch signaling by ROS, a study suggesting the possible mechanism has been reported. Recently, Kavian and his colleagues have reported that ROS could activate Notch pathway in fibroblast model (Kavian et al., 2010). They showed that intradermal ROS can induce the expression of ADAM17 which cleaves the ectodomain of Notch receptor for first step activation of Notch (Kavian et al., 2010). ROS-induced ADAM17 could be a possible factor for activation of Notch signaling in hair follicles. Further researches will be needed on clarify the activation mechanism of Notch signaling by ROS.

\section{3) Tspear}

It has been known that hair follicle morphogenesis and differentiation is dependent on Wnt, Shh, Bmp and Notch signaling pathway interplaying between epithelial and mesenchymal cells. Notch signaling participates in hair follicle morphogenesis in several ways for cell fate decision: lateral inhibition, boundary formation and lineage decision (Bray, 1998). Although, it has been known that Notch has not an essential role in the initial step of embryonic hair follicle development, it plays a key role in cell differentiation in hair follicles during late hair follicle differentiation (Lin et al., 2011; Vauclair et al., 2005). Cell fate is dependent on asymmetrical inheritance of Notch regulators and regulating differentiation and promoting boundary formation by altering adhesive properties of keratinocytes (Bray, 2006). Recently, Peled and his colleagues were reported that mutation in Tspear affects hair follicle morphogenesis in conditional knockdown mouse model (Peled et al., 2016). They further demonstrated that Tspear downregulation lead to transcriptional suppression of Notch1 and its downstream genes in cultured keratinocyte. Although they did not show the detailed mechanism of action of Tspear during tooth and hair follicle morphogenesis, this observation support the possibility that Tspear regulates Notch signaling, a key biological pathway previously shown to affect the development of many ectodermal tissues. Further studies on the molecular mechanism of Tspear regulating Notch signaling remain to be fully delineated.

\section{4) Leptin}

Leptin, a signaling cytokine released by adipocyte, well known as one of the endogenous regulators of body weight and energy metabolism (Farooqi \& O'Rahilly, 2009; Friedman, 
1999-2000). Moreover, it has been reported that leptin can affect cancer progression using the leptin-Notch axis in breast and pancreatic cancers (Battle et al., 2014; Harbuzariu et al., 2017). Recently, leptin has been studied the functional role in skin (Goren et al., 2003; Tadokoro et al., 2015). Leptin and its receptors are expressed by both fibroblasts and keratinocytes and regulate the keratinocyte proliferation for wound repair and skin regeneration. Notably, Sumikawa and his colleagues have been reported that molecular function of leptin in hair cycling (Sumikawa et al., 2014). They demonstrated that leptin was detected in dermal papilla cells in catagen, telogen and early anagen by immunohistochemistry. Moreover, realtime polymerase chain reaction analysis revealed that leptin expressions in dermal papilla cells were upregulated at hypoxic condition during the hair cycle (Sumikawa et al., 2014). Also, Stat3 activation was observed in keratinocytes after the treatment of leptin in vitro (Sumikawa et al., 2014). However, the molecular role of leptin in the bulge region where dermal papilla cells are located has not been studied extensively including hair follicle differentiation. Further studies on the molecular function of leptin and the relevance of the leptinNotch axis are needed to be examined.

\section{Conclusion}

Hair follicle is a very complex miniorgan. Many studies have been found that Notch signaling affects the development process from stem cell self-renewal through progenitor cell differentiation. Furthermore, recent accumulation of stem cell studies of various origins has identified many factors that may influence the Notch signaling in hair follicles during hair follicle development. In this review, we summarize current reports about the various factors that may modulate the signaling of Notch on hair follicle development. These factors have already been reported in cell models of various cell origins and may be suspected of cell-specific activity in the hair follicle development process. In addition, it has already been reported that direct binding of beta-catenin to NICD is possible and that various mutual regulatory mechanisms exist in the cells. In future studies, it is necessary to confirm the possibility of cross-talking of two signaling mechanisms. The information gained from Notch signaling pathway involved in hair follicle development will elucidate in the hair follicle abnormalities arising from their dysregulation. Furthermore, knowledges from depth research on Notch signaling on hair follicle can be applied to stem cell-based therapeutics.

\section{Acknowledgments}

We thank Dr. Sungkwan An (Konkuk University, Korea) for critical feedback and the review.

\section{References}

Artavanis-Tsakonas S, Rand MD, Lake RJ. Notch signaling: cell fate control and signal integration in development. Science, 284: 770-776, 1999.

Aubin-Houzelstein G. Notch signaling and the developing hair follicle. Advances in Experimental Medicine and Biology, 727: 142-160, 2012.

Battle M, Gillespie C, Quarshie A, Lanier V, Harmon T, Wilson K, Torroella-Kouri M, Gonzalez-Perez RR. Obesity induced a leptin-Notch signaling axis in breast cancer. International Journal of Cancer, 134: 1605-1616, 2014.

Blanpain C, Fuchs E. Epidermal stem cells of the skin. Annual Review of Cell and Developmental Biology, 22: 339-373, 2006.

Booth C, Potten CS. Keratinocyte growth factor increases hair follicle survival following cytotoxic insult. Journal of Investigative Dermatology, 114: 667-673, 2000.

Bray S. Notch signalling in Drosophila: three ways to use a pathway. Seminars in Cell \& Developmental Biology, 9: 591-597, 1998.

Bray SJ. Notch signalling: a simple pathway becomes complex. Nature Reviews Molecular Cell Biology, 7: 678-689, 2006.

Brou C, Logeat F, Gupta N, Bessia C, LeBail O, Doedens JR, Cumano A, Roux P, Black RA, Israël A. A novel proteolytic cleavage involved in Notch signaling: the role of the disintegrin-metalloprotease TACE. Molecular Cell, 5: 207216, 2000.

Cai J, Lee J, Kopan R, Ma L. Genetic interplays between Msx2 and Foxn1 are required for Notch1 expression and hair shaft differentiation. Developmental Biology, 326: 420430, 2009.

Chillakuri CR, Sheppard D, Lea SM, Handford PA. Notch receptor-ligand binding and activation: insights from 
molecular studies. Seminars in Cell \& Developmental Biology, 23: 421-428, 2012.

Coulombe PA, Kopan R, Fuchs E. Expression of keratin K14 in the epidermis and hair follicle: insights into complex programs of differentiation. The Journal of Cell Biology, 109: 2295-2312, 1989.

Danilenko DM, Ring BD, Pierce GF. Growth factors and cytokines in hair follicle development and cycling: recent insights from animal models and the potentials for clinical therapy. Molecular Medicine Today, 2: 460-467, 1996.

Eliasson P, Jönsson Jl. The hematopoietic stem cell niche: low in oxygen but a nice place to be. Journal of Cellular Physiology, 222: 17-22, 2010.

Estrach S, Cordes R, Hozumi K, Gossler A, Watt FM. Role of the Notch ligand Delta1 in embryonic and adult mouse epidermis. Journal of Investigative Dermatology, 128: 825-832, 2008.

Ezashi T, Das P, Roberts RM. Low $\mathrm{O}_{2}$ tensions and the prevention of differentiation of hES cells. Proceedings of the National Academy of Sciences of the United States of America, 102: 4783-4788, 2005.

Farooqi IS, O'Rahilly S. Leptin: a pivotal regulator of human energy homeostasis. The American Journal of Clinical Nutrition, 89: 980S-984S, 2009.

Favier B, Fliniaux I, Thélu J, Viallet JP, Demarchez M, Jahoda CA, Dhouailly D. Localisation of members of the notch system and the differentiation of vibrissa hair follicles: receptors, ligands, and fringe modulators. Developmental Dynamics, 218: 426-437, 2000.

Fehrer C, Brunauer R, Laschober G, Unterluggauer $\mathrm{H}$, Reitinger S, Kloss F, Gülly C, Gassner R, Lepperdinger G. Reduced oxygen tension attenuates differentiation capacity of human mesenchymal stem cells and prolongs their lifespan. Aging Cell, 6: 745-757, 2007.

Fischer TW, Hipler UC, Elsner P. Effect of caffeine and testosterone on the proliferation of human hair follicles in vitro. International Journal of Dermatology, 46: 27-35, 2007.

Friedman JM. Leptin and the regulation of body weight. Harvey Lectures, 95: 107-136, 1999-2000.

Goren I, Pfeilschifter J, Frank S. Determination of leptin signaling pathways in human and murine keratinocytes. Biochemical and Biophysical Research Communications, 303: 1080-1085, 2003.
Grbavec D, Stifani S. Molecular interaction between TLE1 and the carboxyl-terminal domain of HES-1 containing the WRPW motif. Biochemical and Biophysical Research Communications, 223: 701-705, 1996.

Hamanaka RB, Chandel NS. Mitochondrial metabolism as a regulator of keratinocyte differentiation. Cellular Logistics, 3: 25456, 2013.

Hamanaka RB, Glasauer A, Hoover P, Yang S, Blatt H, Mullen AR, Getsios S, Gottardi CJ, DeBerardinis RJ, Lavker RM, et al. Mitochondrial reactive oxygen species promote epidermal differentiation and hair follicle development. Science Signaling, 6: ra8, 2013.

Handy DE, Loscalzo J. Redox regulation of mitochondrial function. Antioxidants \& Redox Signaling, 16: 13231367, 2012.

Harbuzariu A, Rampoldi A, Daley-Brown DS, Candelaria P, Harmon TL, Lipsey CC, Beech DJ, Quarshie A, llies GO, Gonzalez-Perez RR. Leptin-Notch signaling axis is involved in pancreatic cancer progression. Oncotarget, 8: 77407752, 2017.

Hoffmann R, Eicheler W, Huth A, Wenzel E, Happle R. Cytokines and growth factors influence hair growth in vitro: possible implications for the pathogenesis and treatment of alopecia areata. Archives of Dermatological Research, 288: 153-156, 1996.

Holub BS, Kloepper JE, Tóth BI, Bíro T, Kofler B, Paus R. The neuropeptide galanin is a novel inhibitor of human hair growth. British Journal of Dermatology, 167: 10-16, 2012.

Horisawa K, Imai T, Okano H, Yanagawa H. 3'-Untranslated region of doublecortin $\mathrm{mRNA}$ is a binding target of the Musashi1 RNA-binding protein. FEBS Letters, 583: 24292434, 2009.

Horisawa K, Imai T, Okano H, Yanagawa H. The Musashi family RNA-binding proteins in stem cells. Biomolecular Concepts, 1: 59-66, 2010.

Imai T, Tokunaga A, Yoshida T, Hashimoto M, Mikoshiba K, Weinmaster G, Nakafuku M, Okano H. The neural RNAbinding protein Musashi1 translationally regulates mammalian numb gene expression by interacting with its mRNA. Molecular and Cellular Biology, 21: 3888-3900, 2001.

Iso T, Kedes L, Hamamori Y. HES and HERP families: multiple effectors of the Notch signaling pathway. Journal of Cellular Physiology, 194: 237-255, 2003. 
Kavian N, Servettaz A, Mongaret C, Wang A, Nicco C, Chéreau C, Grange P, Vuiblet V, Birembaut P, Diebold MD, et al. Targeting ADAM-17/notch signaling abrogates the development of systemic sclerosis in a murine model. Arthritis \& Rheumatology, 62: 3477-3487, 2010.

Kopan R, Ilagan MX. The canonical Notch signaling pathway: unfolding the activation mechanism. Cell, 137: 216-233, 2009.

Krebs LT, Deftos ML, Bevan MJ, Gridley T. The Nrarp gene encodes an ankyrin-repeat protein that is transcriptionally regulated by the notch signaling pathway. Developmental Biology, 238: 110-119, 2001.

Kuroda K, Han H, Tani S, Tanigaki K, Tun T, Furukawa T, Taniguchi Y, Kurooka H, Hamada Y, Toyokuni S, et al. Regulation of marginal zone B cell development by MINT, a suppressor of Notch/RBP-J signaling pathway. Immunity, 18: 301312, 2003.

Lee J, Tumbar T. Hairy tale of signaling in hair follicle development and cycling. Seminars in Cell \& Developmental Biology, 23: 906-916, 2012.

Lemasters JJ, Ramshesh VK, Lovelace GL, Lim J, Wright GD, Harland D, Dawson TL Jr. Compartmentation of mitochondrial and oxidative metabolism in growing hair follicles: a ring of fire. Journal of Investigative Dermatology, 137: 1434-1444, 2017.

Limat A, Salomon D, Carraux P, Saurat JH, Hunziker T. Human melanocytes grown in epidermal equivalents transfer their melanin to follicular outer root sheath keratinocytes. Archives of Dermatological Research, 291: 325-332, 1999.

Lin HY, Kao CH, Lin KM, Kaartinen V, Yang LT. Notch signaling regulates late-stage epidermal differentiation and maintains postnatal hair cycle homeostasis. PLoS One, 6: 15842, 2011.

Lin KK, Chudova D, Hatfield GW, Smyth P, Andersen B. Identification of hair cycle-associated genes from timecourse gene expression profile data by using replicate variance. Proceedings of the National Academy of Sciences of the United States of America, 101: 1595515960, 2004.

Lin KK, Kumar V, Geyfman M, Chudova D, Ihler AT, Smyth P, Paus R, Takahashi JS, Andersen B. Circadian clock genes contribute to the regulation of hair follicle cycling. PLOS Genetics, 5: 1000573, 2009.
Logeat F, Bessia C, Brou C, LeBail O, Jarriault S, Seidah NG, Israël A. The Notch1 receptor is cleaved constitutively by a furin-like convertase. Proceedings of the National Academy of Sciences of the United States of America, 95: 8108-8112, 1998.

Ma X, Tian Y, Song Y, Shi J, Xu J, Xiong K, Li J, Xu W, Zhao Y, Shuai J, et al. Msi2 maintains quiescent state of hair follicle stem cells by directly repressing the Hh signaling pathway. Journal of Investigative Dermatology, 137: 10151024, 2017.

Matsuno K, Diederich RJ, Go MJ, Blaumueller CM, ArtavanisTsakonas S. Deltex acts as a positive regulator of Notch signaling through interactions with the Notch ankyrin repeats. Development, 121: 2633-2644, 1995.

McGill MA, McGlade CJ. Mammalian numb proteins promote Notch1 receptor ubiquitination and degradation of the Notch1 intracellular domain. Journal of Biological Chemistry, 278: 23196-23203, 2003.

Mohyeldin A, Garzón-Muvdi T, Quiñones-Hinojosa A. Oxygen in stem cell biology: a critical component of the stem cell niche. Cell Stem Cell, 7: 150-161, 2010.

Ohyama M. Hair follicle bulge: a fascinating reservoir of epithelial stem cells. Journal of Dermatological Science, 46: 81-89, 2007.

Okano H, Imai T, Okabe M. Musashi: a translational regulator of cell fate. Journal of Cell Science, 115: 1355-1359, 2002.

Okano H, Kawahara H, Toriya M, Nakao K, Shibata S, Imai T. Function of RNA-binding protein Musashi-1 in stem cells. Experimental Cell Research, 306: 349-356, 2005.

Pan Y, Lin MH, Tian X, Cheng HT, Gridley T, Shen J, Kopan R. Gamma-secretase functions through Notch signaling to maintain skin appendages but is not required for their patterning or initial morphogenesis. Developmental Cell, 7: 731-743, 2004.

Paus R, Müller-Röver S, Van Der Veen C, Maurer M, Eichmüller S, Ling G, Hofmann U, Foitzik K, Mecklenburg L, Handjiski B. A comprehensive guide for the recognition and classification of distinct stages of hair follicle morphogenesis. Journal of Investigative Dermatology, 113: 523-532, 1999.

Peled A, Sarig O, Samuelov L, Bertolini M, Ziv L, WeissglasVolkov D, Eskin-Schwartz M, Adase CA, Malchin N, Bochner $\mathrm{R}$, et al. Mutations in TSPEAR, encoding a 
regulator of Notch signaling, affect tooth and hair follicle morphogenesis. PLoS Genetics, 12: 1006369, 2016.

Plikus MV, Mayer JA, de la Cruz D, Baker RE, Maini PK, Maxson R, Chuong CM. Cyclic dermal BMP signalling regulates stem cell activation during hair regeneration. Nature, 451: 340-344, 2008.

Powell BC, Passmore EA, Nesci A, Dunn SM. The Notch signalling pathway in hair growth. Mechanisms of Development, 78: 189-192, 1998.

Powell BC, Rogers GE. Cyclic hair-loss and regrowth in transgenic mice overexpressing an intermediate filament gene. The EMBO Journal, 9: 1485-1493, 1990.

Rana NA, Haltiwanger RS. Fringe benefits: functional and structural impacts of O-glycosylation on the extracellular domain of Notch receptors. Current Opinion in Structural Biology, 21: 583-589, 2011.

Rishikaysh P, Dev K, Diaz D, Qureshi WM, Filip S, Mokry J. Signaling involved in hair follicle morphogenesis and development. International Journal of Molecular Sciences, 15: 1647-1670, 2014.

Sakakibara S, Imai T, Hamaguchi K, Okabe M, Aruga J, Nakajima K, Yasutomi D, Nagata T, Kurihara Y, Uesugi $\mathrm{S}$, et al. Mouse-Musashi-1, a neural RNA-binding protein highly enriched in the mammalian CNS stem cell. Developmental Biology, 176: 230-242, 1996.

Sakakibara S, Nakamura Y, Satoh H, Okano H. Rna-binding protein Musashi2: developmentally regulated expression in neural precursor cells and subpopulations of neurons in mammalian CNS. The Journal of Neuroscience, 21: 8091-8107, 2001.

Sato C, Zhao G, llagan MX. An overview of notch signaling in adult tissue renewal and maintenance. Current Alzheimer Research, 9: 227-240, 2012.

Schlake T. Determination of hair structure and shape.
Seminars in Cell \& Developmental Biology, 18: 267-273, 2007.

Schneider MR, Schmidt-Ullrich R, Paus R. The hair follicle as a dynamic miniorgan. Current Biology, 19: 132-142, 2009.

Struhl G, Greenwald I. Presenilin-mediated transmembrane cleavage is required for Notch signal transduction in Drosophila. Proceedings of the National Academy of Sciences of the United States of America, 98: 229-234, 2001.

Sugiyama-Nakagiri Y, Akiyama M, Shibata S, Okano H, Shimizu H. Expression of RNA-binding protein Musashi in hair follicle development and hair cycle progression. The American Journal of Pathology, 168: 80-92, 2006.

Sumikawa Y, Inui S, Nakajima T, Itami S. Hair cycle control by leptin as a new anagen inducer. Experimental Dermatology, 23: 27-32, 2014.

Tadokoro S, Ide S, Tokuyama R, Umeki H, Tatehara S, Kataoka $\mathrm{S}$, Satomura K. Leptin promotes wound healing in the skin. PLoS One, 10: 0121242, 2015.

Tang Y, Luo B, Deng Z, Wang B, Liu F, Li J, Shi W, Xie H, Hu X, $\mathrm{Li}$ J. Mitochondrial aerobic respiration is activated during hair follicle stem cell differentiation, and its dysfunction retards hair regeneration. PeerJ, 4: 1821-1835, 2016.

van Beek N, Bodó E, Kromminga A, Gáspár E, Meyer K, Zmijewski MA, Slominski A, Wenzel BE, Paus R. Thyroid hormones directly alter human hair follicle functions: anagen prolongation and stimulation of both hair matrix keratinocyte proliferation and hair pigmentation. The Journal of Clinical Endocrinology \& Metabolism, 93: 4381-4388, 2008.

Vauclair S, Nicolas M, Barrandon Y, Radtke F. Notch1 is essential for postnatal hair follicle development and homeostasis. Developmental Biology, 284: 184-193, 2005. 


\section{국문초록}

\section{모낭 발달에 있어서의 Notch 신호전달체계의 역할}

배승희 ${ }^{1}$, 이기헌 ${ }^{2}$, 이인호 ${ }^{2}$, 김미경 ${ }^{2}$, 이재호 ${ }^{3 *}$

${ }^{1}$ 건국대학교 화장품공학과 질병분자표적신약연구소, 서울, 한국

${ }^{2}$ 단국대학교 의과대학 제일병원 산부인과, 서울, 한국

${ }^{3}$ 단국대학교 의과대학 제일병원 분자종양학교실, 서울, 한국

Notch 신호전달체계는 줄기세포의 항상성 조절뿐만 아니라 모낭을 포함한 다세포 조직의 발달 조절에도 주요한 역할을 담당한다. 다양한 연구논문을 통해 Notch 활성은 모낭 발달과정에 있어 세포의 운명을 결정하는데 매우 중대한 역할을 수행한다고 밝혀졌다. 또한, 모낭 줄기세포의 운명 조절과 모발 주기 조절 그리고 손상된 두피의 재건에도 중심적인 역할을 담당한다고 보고되고 있다. 게 다가 모구에 있어 Notch 신호전달체계는 모낭줄기세포의 분화 조절까지 그 기능이 보고되고 있다. 본 총설은 모낭의 발달 및 모낭 의 항상성 유지에 관여하는 Notch 신호전달체계 및 관련 조절 단백질들에 대한 최신 지견을 요약하고자 한다.

핵심어: Notch, 모낭, 줄기세포, 성장, 발달

본 논문을 위해 조언해주신 건국대학교 안성관 교수님께 감사의 말씀을 드립니다. 


\section{中文摘要}

\section{Notch 信号在毛囊发育中的作用}

裴承熙 ${ }^{1}$, 李寄憲 ${ }^{2}$, 李仁鎬 ${ }^{2}$, 金美京 $^{2}$, 李在鎬 $^{3 *}$

建国大学化妆品工学科疾病分子靶标新药研究所, 首尔, 韩国

${ }^{2}$ 檀国大学医科大学第一医院妇产科, 首尔, 韩国

3檀国大学医科大学第一医院分子肿瘤科，首尔，韩国

Notch信号通路被认为是不仅调节干细胞稳态，而且调节包括毛囊在内的多细胞组织发育的重要信号转导途径。许多研究 表明, 在毛囊发育过程中, Notch活性在细胞命运决定方面起着关键作用。还有越来越多的研究结果表明, Notch信号通 路在控制毛囊干细胞命运、调控毛发周期和损伤毛发器官再生方面起着关键性的作用。此外，在毛球中，Notch信号通路 调节毛囊干细胞分化方面发挥了重要作用。本文综述了近年来参与毛囊发育和维持毛囊稳态的Notch信号通路以及相关调 控蛋白的最新研究进展。

关键词: Notch，毛囊，干细胞，生长，发育 